\title{
Mechanisms of Trichoderma longibrachiatum T6 Fermentation against Valsa mali through Inhibiting Its Growth and Reproduction, Pathogenicity and Gene Expression
}

\author{
Na Zhu ${ }^{1,2} \mathbb{D}$, Jing-Jiang Zhou ${ }^{1,3}$, Shu-Wu Zhang ${ }^{1,4, *}$ and Bing-Liang $\mathrm{Xu}{ }^{1,2, *}$ \\ 1 College of Plant Protection, Gansu Agricultural University, Lanzhou 730070, China; zhuna54@163.com (N.Z.); \\ jzhou@gsau.edu.cn (J.-J.Z.) \\ 2 Gansu Provincial Biocontrol Engineering Laboratory of Crop Diseases and Pests, Lanzhou 730070, China \\ 3 State Key Laboratory of Green Pesticide and Agricultural Bioengineering, Ministry of Education, \\ Guizhou University, Guiyang 550025, China \\ 4 Gansu Provincial Key Laboratory of Arid Land Crop Science, Gansu Agricultural University, \\ Lanzhou 730070, China \\ * Correspondence: zhangsw704@126.com (S.-W.Z.); xubl@gsau.edu.cn (B.-L.X.)
}

Citation: Zhu, N.; Zhou, J.-J.; Zhang, S.-W.; Xu, B.-L. Mechanisms of Trichoderma longibrachiatum T6 Fermentation against Valsa mali through Inhibiting Its Growth and Reproduction, Pathogenicity and Gene Expression. J. Fungi 2022, 8, 113. https://doi.org/10.3390/jof8020113

Academic Editor: Kuang R. Chung

Received: 22 November 2021

Accepted: 19 January 2022

Published: 25 January 2022

Publisher's Note: MDPI stays neutral with regard to jurisdictional claims in published maps and institutional affiliations.

Copyright: (C) 2022 by the authors. Licensee MDPI, Basel, Switzerland. This article is an open access article distributed under the terms and conditions of the Creative Commons Attribution (CC BY) license (https:// creativecommons.org/licenses/by/ $4.0 /)$.

\begin{abstract}
Apple Valsa canker is one of the most serious diseases, having caused significant apple yield and economic loss in China. However, there is still no effective biological methods for controlling this disease. Our present study focused on the inhibitory activity and mechanisms of Trichoderma longibrachiatum (T6) fermentation on Valsa mali that causes apple Valsa canker (AVC). Our results showed that the T6 fermentation exhibited effective antifungal activity on the mycelial growth and conidia germination of $V$. mali, causing mycelium malformation and the hyphal disintegrating in comparison to the control. The activity of pathogenically related enzymes that are secreted from $V$. mali and the expression level of gene of $V$. mali were significantly inhibited and downregulated by treatment with T6 fermentation. In addition, the lesion area and number of pycnidia of $V$. mali formed on the branches were significantly reduced after treatment with the T6 fermentation through the pathogenicity test on the detached branches. Our results indicate that the possible mechanism of T6 fermentation against $V$. mali occurs through inhibiting its growth and reproduction, the pathogenic enzyme activity, and its related gene expression.
\end{abstract}

Keywords: Trichoderma longibrachiatum (T6); biological control; Valsa mali; pathogenicity

\section{Introduction}

Apple Valsa canker is a devastating disease that caused by Valsa mali [1], which results in significant damages to apple production and huge economic losses in East Asia [2]. It is one of the important factors limiting apple production in Japan [3] and South Korea [4]. In China, apple Valsa canker is considered as one of the devastating diseases in apple orchards, restricting the yield and quality of apple fruits and causing great economic losses to the apple industry every year [5,6]. Although apple Valsa canker has been occurring and seriously damaging apple orchards, there is no effective control method [7].

Currently, chemical control is the main method for apple Valsa canker control [8-10], due to the limitation of resistant breeding against apple Valsa canker [11,12]. However, there are increasing concerns regarding to the impact of chemical fungicides on environmental pollution. Many chemical fungicides have been also challenged by the resistance development to pathogens [13]. Furthermore, V. mali mainly invades the phloem and xylem of apple trees, which makes it difficult to control with conventional fungicide treatments [14]. In order for a substantial increase in plants production to be maintained and for the growing demand for food and environmental quality to be met, biological agents have been widely used to control plant diseases because they are environmentally more friendly [15]. 
Some biocontrol agents used to control plant diseases have been reported widely in recent years $[16,17]$. Trichoderma is one of the widely distributed and broad-spectrum biocontrol fungi, i.e., the secondary metabolites of Trichoderma play an important role in controlling of plant disease $[18,19]$. A number of reports have revealed that the fermentation of Trichoderma had a significant inhibitory effect on different species of plant pathogens [20,21]. However, the previous studies mainly focused on the effect of the pathogens on mycelial morphology and growth, and only few reports have focused on the inhibitory effect of Trichoderma longibrachiatum T6 (T6) on V. mali gene expression and reproduction. T6 is a wellknown biological control agent against several plant pathogens with limited harm to the environment. Our previous study reported that T6 fermentation has been shown to have an inhibitory effect on 11 pathogens (Phaeoramularia capsicicola, Colletotrichum lindemuthianum, Fusarium semitectum, Rhizoctonia solani, Alternaria mali, Botrytis cinerea, Trichothecium roseum, Fusarium oxysporum, Aspergillus niger, Rhizopus nigricans, V. mali) [22], and the average inhibitory rate of T6 strain on Fusarium oxysporum was 60.09\% [23]. However, there is little information regarding to the mechanisms of $\mathrm{T} 6$ fermentation against $V$. mali.

A previous study reported that the mechanism for the infection of $V$. mali in the host was due to the secretion multiple of cell wall degrading enzymes (CWDEs) that include xylanase, $\beta$-glucosidase, cellulase (Cx), polygalacturonase (PG), and polymethylgalacturonase (PMG) [24]. Research has shown that the activity of polygalacturonase, polymethylgalacturonase, cellulase, $\beta$-glucosidase, and xylanase was closely related to $V$. mali pathogenicity during infection of apple tree $[24,25]$. In addition, some studies with cytochemistry, genomic, and transcriptome sequencing demonstrated that pectinase plays an important role in the infection process of $V$. mali $[14,26,27]$. The expression of the genes related to pectin catabolism, hydrolase activity, and biosynthesis of secondary metabolites increased during V. mali infection of apple tree [27]. The genes of VmVeA, VmVelB Gvm2, and Gvm3 are involved in growth, conidial development, secondary metabolism, and virulence of $V$. mali $[28,29]$. However, there is little information regarding to the effect of T6 fermentation on the activities of CWDEs and its related gene expression at biochemical and molecular levels.

The purposes of this study were to determine the antifungal activity of T6 fermentation against $V$. mali at morphological, biochemical, and molecular levels; the effect of T6 fermentation on the pathogenicity, conidia germination, and mycelial growth of $V$. mali; the effect of T6 fermentation on the activity of CWDEs of $V$. mali; and the gene expression of $V$. mali. Our results will provide new insights into the biological control mechanism of T6 fermentation against $V$. mali.

\section{Materials and Methods}

\subsection{Preparation of Pathogen and Antagonistic Strain}

Valsa mali and antagonistic strain of Trichoderma longibrachiatum (T6) were provided by the Laboratory of Plant Virology and Molecular Biology, Gansu Agricultural University. The antagonistic strain T6 is also deposited in the Institute of Microbiology, Chinese Academy of Sciences, with the accession number of CGMCC no.13183. The V. mali and T6 were grown on potato dextrose agar (PDA) (dextrose: China pharmaceutical group, Beijing, China; agar: Solarbio, Beijing, China) in Petri dishes for 5 and 6 days, respectively, at $25^{\circ} \mathrm{C}$ with a $16 \mathrm{~h}$ light $/ 8 \mathrm{~h}$ dark photoperiod regime.

\subsection{Preparation of T6 Fermentation}

The conidia suspension of $\mathrm{T} 6$ was obtained by flushing the conidia of 6-day-old T6 from PDA culture with $5 \mathrm{~mL}$ of sterilized water into a sterile $10 \mathrm{~mL}$ centrifuge tube after adding a drop of Tween-80. The conidia were suspended by shaking and adjusted to $1.5 \times 10^{7}$ conidia per milliter using a hemocytometer (Qiu Jing, Shanghai, China). The conidia suspension of T6 $(1 \mathrm{~mL})$ was mixed with $60 \mathrm{~mL}$ of sterilized liquid potato dextrose broth (PDB) culture medium in an Erlenmeyer flask $(150 \mathrm{~mL})$ and fermented for 7 days with shaking at $150 \mathrm{r} / \mathrm{min}$ and $28^{\circ} \mathrm{C}$. The fermentation was then filtered through a filter paper 
(Whatman Paper No. 3) and centrifuged at $12,000 \mathrm{r} / \mathrm{min}$ for $15 \mathrm{~min}$ at $4{ }^{\circ} \mathrm{C}$. The supernatant was filtered with $0.22 \mu \mathrm{m}$ Millipore membranes. Finally, the sterile T6 fermentation was stored as the stock solution at $4{ }^{\circ} \mathrm{C}$ for the experiments described below.

\subsection{Determination of Antifungal Activity of T6 Fermentation}

The sterile stock solution of $\mathrm{T} 6$ fermentation was diluted to $0-, 2-, 4-, 8-, 16-$, and 32 -fold with sterile water, and $0.5 \mathrm{~mL}$ of each diluted fermentation was added to $20 \mathrm{~mL}$ of PDA plate $(8.5 \mathrm{~cm}$ in diameter). The same amount of sterile water in place of the fermentation was used as the control. The mycelial disc ( $5 \mathrm{~mm}$ in diameter) of 5-day-old $V$. mali culture was transferred to the center of each PDA plate and cultured at $25^{\circ} \mathrm{C}$. Six PDA plates were used for each fermentation dilution and sterile water. After being inoculated 5 days on the PDA medium at $25^{\circ} \mathrm{C}$, the growth of $\mathrm{V}$. mali mycelium was observed and recorded every $24 \mathrm{~h}$ until $\mathrm{V}$. mali was fully grew on the control plates without T6 fermentation. The level of the antifungal activity of T6 fermentation was calculated as the inhibitory rate (n) according to the formula $\mathrm{n}(\%)=[(\mathrm{a}-\mathrm{b}) / \mathrm{a}] \times 100$, where a is the colony area of $V$. mali without T6 fermentation on the control PDA medium, and $\mathrm{b}$ is the colony area of $V$. mali on the PDA medium treated with T6 fermentation [30]. The number of pycnidia produced on the colony of $V$. mali was recorded at 20 days of after inoculation. The experiment was performed with six replicates for each fermentation dilution and control.

\subsection{Examination of Conidia Germination and Mycelial Growth of V. mali}

For the determination of conidia germination, the $V$. mali conidia were collected from the pycnidia on apple tree branches and suspended in the T6 fermentation at the concentration of $10^{7}$ conidia per milliliter conidia suspension. The conidia suspension $(20 \mu \mathrm{L})$ was evenly placed on the PDA media with a sterilized applicator and then cultured at $25{ }^{\circ} \mathrm{C}$ for $0-30 \mathrm{~h}$. The germination of the conidia was observed under a light microscope (Nikon, Japan). The germination rate was recorded when the length of germ tube was more than half of the diameter of conidia. Sterile water instead of the T6 fermentation was used as the control.

To determine the mycelial growth of $V$. mali under different densities of $\mathrm{T} 6$ fermentation (dilutions at 0-, 2-, 4-, 8-, 16-, and 32-fold), we added $1 \mathrm{~mL}$ of each $\mathrm{T} 6$ fermentation dilution into a $150 \mathrm{~mL}$ Erlenmeyer flask containing $60 \mathrm{~mL}$ of PDB medium. A total of $1 \mathrm{~mL}$ of sterile water was used as control in a separate flask. Then, a 5-day-old V. mali mycelial disc (5 mm in diameter) was added into the PDB medium and inoculated with shaking at $25^{\circ} \mathrm{C}$ and $150 \mathrm{r} / \mathrm{min}$. The mycelium in either different $\mathrm{T} 6$ fermentation dilutions or water were obtained by filtration with sterile filter paper at 5 days after incubation. The mycelial morphology of $V$. mali was observed and photographed with light microscope (Nikon, Tokyo, Japan) and scanning electron microscope (Hitachi, Tokyo, Japan). The dry weight of the mycelium was recorded after air drying.

\subsection{Determination of the Pathogenicity of V. mali on Detached Twig Branches}

Two-year-old healthy apple branches of the "Fuji" variety were cut into $15 \mathrm{~cm}$ segments, washed twice with tap water, and disinfected with $75 \%$ alcohol. The twigs were then rinsed with sterile water 3 times, and both ends of the twigs were sealed with paraffin wax after they dried. The twigs were scalded with hot iron nail caps ( $5 \mathrm{~mm}$ in diameter) at a certain distance [31], each twig with three scalded areas. The 5-day-old mycelial discs ( $5 \mathrm{~mm}$ in diameter) of $V$. mali were inoculated on the scalded area, and the inoculated twigs were maintained in a moisture-controlled chamber at $25^{\circ} \mathrm{C}$ and covered with fresh-keeping film. After $24 \mathrm{~h}$, the T6 fermentation stock solution was sprayed on the inoculation sites before appearance of lesions. The same amount of sterile water was applied on the twigs as a control. The size of lesions and the number of pycnidia were measured and recorded regularly at 3, 5, 7, 9, 12, and 15 days after the inoculation. Three detached twigs were used for each treatment and control, separately, and the experiments were repeated three times. 


\subsection{Assay of the Cell Wall-Degrading Enzyme Activity of V. mali}

Three $V$. mali mycelial discs ( $5 \mathrm{~mm}$ in diameter) were taken from the edge of $V$. mali on PDA plates and added individually into each of the sterilized flasks $(150 \mathrm{~mL})$ containing $60 \mathrm{~mL}$ synthetic medium (SM). The SM contained $\mathrm{KH}_{2} \mathrm{PO}_{4}(0.4 \mathrm{~g}), \mathrm{MgSO}_{4} \cdot 7 \mathrm{H}_{2} \mathrm{O}(0.2 \mathrm{~g}), \mathrm{KCl}$ $(0.2 \mathrm{~g}), \mathrm{NH}_{4} \mathrm{NO}_{3}(1 \mathrm{~g}), \mathrm{FeSO}_{4}(0.01 \mathrm{~g}), \mathrm{ZnSO}_{4}(0.01 \mathrm{~g})$, and $\mathrm{MnSO}_{4}(0.01 \mathrm{~g})$ in $1 \mathrm{~L}$ distilled water [32]. Thereafter, $1 \mathrm{~mL}$ of $\mathrm{T} 6$ fermentation stock solution was added in each flask, and the mixtures were incubated on the shaker at $150 \mathrm{r} / \mathrm{min}$ at $25^{\circ} \mathrm{C}$ for 11 days, whereas $1 \mathrm{~mL}$ of sterile water was used as control. The culture filtrate $(10 \mathrm{~mL})$ was sampled from each flask at 3, 5, 7, 9 and 11 days by centrifuging at $8000 \mathrm{r} / \mathrm{min}$ at $4{ }^{\circ} \mathrm{C}$ for $15 \mathrm{~min}$ and was filtered through $0.22 \mu \mathrm{m}$ Millipore membranes after incubation. The activities of pectinase, xylanase, and cellulase were determined with the dinitrosalicylic acid (DNS) method using $1 \%(w / v)$ pectin, xylan, and carboxymethyl cellulose as the substrates, respectively [33]. The culture filtrate $(500 \mu \mathrm{L})$ was mixed with $2.5 \mathrm{~mL}$ of $1 \%(w / v)$ either pectin or xylan or carboxymethyl cellulose in $50 \mathrm{mM}$ sodium citrate buffer ( $\mathrm{pH}$ 5.0) and incubated at $50{ }^{\circ} \mathrm{C}$ for $30 \mathrm{~min}$, and then $3 \mathrm{~mL}$ of the DNS solution was added to each reaction mixture and boiled for $5 \mathrm{~min}$. The absorbance of the reaction mixtures was measured at $540 \mathrm{~nm}$ with a spectrophotometer. One unit of pectinase, xylanase, and cellulase activity (U) was defined as the amount of the enzyme that catalyses pectin, xylan, and carboxymethyl to $1 \mu \mathrm{mol}$ of D-galacturonic acid, xylose, and glucose per minute, respectively. Each treatment and control were performed with six replications.

\subsection{Measurement of Gene Expression in V. mali before and after T6 Fermentation Treatment}

Three mycelial discs were taken from a well-grown $V$. mali colony and put into the mixture of $60 \mathrm{~mL}$ of PDB medium and $1 \mathrm{~mL}$ of $\mathrm{T} 6$ fermentation and incubated at $25^{\circ} \mathrm{C}$ and $150 \mathrm{r} / \mathrm{min}$ shaking. Sterile water was used instead of the T6 fermentation as the control. After cultivating for 5 days, the mycelium was collected by centrifuging at 12,000 r/min for $15 \mathrm{~min}$ and stored at $-80^{\circ} \mathrm{C}$ for later use.

Total RNA of the mycelium was extracted using the Fungal RNA Kit (Omega Bio-Tek, Norcross, GA, USA) and stored at $-80^{\circ} \mathrm{C}$. RNA integrity was checked with $1 \%$ agarose gel electrophoresis and the radios of $\mathrm{OD}_{260} / \mathrm{OD}_{280}$ and $\mathrm{OD}_{260} / \mathrm{OD}_{230}$. The concentration of the total RNA was determined by UV spectrophotometer (Implen NanoPhotometer, Munich, Germany). The first-strand cDNA was synthesized according to the instructions of the first-strand cDNA synthesis kit (Takara Bio-Tek, Dalian, China) and stored at $-20{ }^{\circ} \mathrm{C}$. The expression level of 15 genes were detected by RT-qPCR. These genes were demonstrated by the previous transcriptome analysis that relate to the cell wall-degrading enzyme, growth, metabolism, and pathogenicity of $V$. mali [34]. The primers of the selected genes were designed by Primer Premier 5.0 and listed in Table S1. The kits of TB Green ${ }^{\circledR}$ Premix Ex Taq ${ }^{\mathrm{TM}}$ II (Takara Bio-Tek, Dalian, China) and instrument of applied biosystems quantstudio ${ }^{\mathrm{TM}}$ 5 real-time PCR (Thermo Fisher Scientific, Waltham, MA, USA) were used for RT-qPCR reactions and gene expression determination, respectively. Total volume of reaction system was $20 \mu \mathrm{L}$, and the RT-qPCR analysis was repeated three times for each gene. The relative expression level was calculated by REST 2009 Software (Quiagen, Dusseldorf, Germany). The glucose-6-phosphate-dehydrogenase (G6PDH) and cyclophilin (CYP) genes were selected as the endogenous reference genes [35], and the Vm sample was used as control for the calculation of the relative expression levels.

\section{Results}

\subsection{Inhibition of Colony Growth and Pycnidial Formation of V. mali by T6 Fermentation}

The experimental results showed that $\mathrm{T} 6$ fermentation had a significantly inhibitory effect on the mycelial growth and pycnidia production of $V$. mali on PDA in Petri dishes (Figure 1, Table 1). Compared with the control, T6 fermentation significantly inhibited the $V$. mali growth after 5 days of inoculation. The colony diameter of $V$. mali treated with T6 fermentation was smaller than that of control under all treatments (Figure 1A). The highest inhibitory rates $(94.86 \%)$ were observed on V. mali treated with the T6 fermentation without 
dilution. The inhibitory rates were $89.63 \%$ in $V$. mali treated with twofold dilution. The inhibitory rates decreased with the increase of dilution fold with the lowest inhibitory rate of $38.91 \%$ when the fermentation was diluted by 32-fold (Table 1). In addition, the number of pycnidia produced by $V$. mali treated with $\mathrm{T} 6$ fermentation was lower than that of the treated with sterile water after inoculation for 20 days (Figure 1B). The V. mali treated with stock solution of T6 fermentation (0-fold) did not produce any pycnidia on PDA at 20 days. With the increase of dilution fold, the number of pycnidia produced gradually increased. The numbers of pycnidia produced by $V$. mali were $22.67 \pm 4.93$ and $157.5 \pm 6.63$ after being treated with twofold and 32-fold dilution, respectively, while $227.83 \pm 12.35$ of pycnidia was produced by $V$. mali treated with sterile water (Table 1 ).

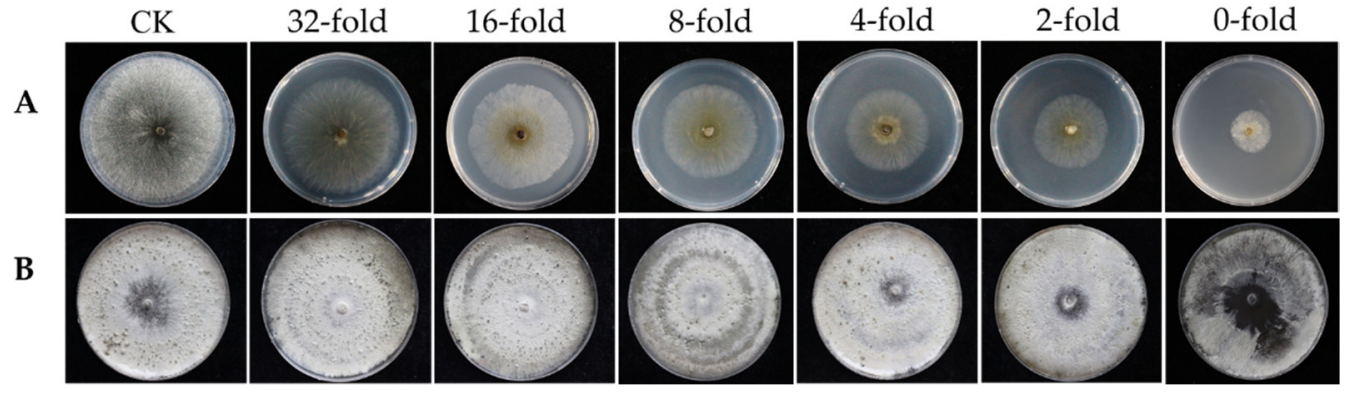

Figure 1. Inhibitory effect of different dilutions of Trichoderma longibrachiatum T6 fermentation on Valsa mali on PDA media. (A) Colony growth. (B) Pycnidia production. The dilution folds are indicated above images. CK is the control without T6 treatment.

Table 1. Effect of different dilutions of Trichoderma longibrachiatum T6 fermentation on the colony and pycnidia production of Valsa mali on the PDA media after 20 days incubation.

\begin{tabular}{cccc}
\hline $\begin{array}{c}\text { Dilutions } \\
\text { (Folds) }\end{array}$ & $\begin{array}{c}\text { Colony Diameters } \\
(\mathbf{c m})\end{array}$ & $\begin{array}{c}\text { Inhibitory Rates } \\
\mathbf{( \% )}\end{array}$ & $\begin{array}{c}\text { Pycnidia Amounts } \\
\text { (Pycnidia per Media) }\end{array}$ \\
\hline 0 & 1.93 & $94.86 \pm 0.47^{\mathrm{a}}$ & $0.00 \pm 0.00 \mathrm{~g}$ \\
2 & 2.73 & $89.63 \pm 1.19^{\mathrm{b}}$ & $22.67 \pm 4.93^{\mathrm{f}}$ \\
4 & 4.17 & $75.97 \pm 0.70^{\mathrm{c}}$ & $41.17 \pm 4.02^{\mathrm{e}}$ \\
8 & 4.67 & $69.85 \pm 0.98^{\mathrm{d}}$ & $59.50 \pm 6.09^{\mathrm{d}}$ \\
16 & 5.61 & $56.46 \pm 1.42^{\mathrm{e}}$ & $125.00 \pm 9.38^{\mathrm{c}}$ \\
32 & 6.64 & $38.91 \pm 3.26^{\mathrm{f}}$ & $157.50 \pm 6.63^{\mathrm{b}}$ \\
$\mathrm{ck}$ & 8.50 & - & $227.83 \pm 12.35^{\mathrm{a}}$ \\
\hline
\end{tabular}

Value are means \pm standard deviations of six replicates, and the different lowercase letters in the same column are significantly different at $p<0.05$ according to Duncan's new multiple range test and least significant difference test

The inhibitory rates $(\%)$ and pycnidia amount were determined on the 5th and 20th days after inoculation with V. mali. "0" represents stock solution of $\mathrm{T} 6$ fermentation. ck represents sterile water instead of $\mathrm{T} 6$ fermentation.

\subsection{Inhibitory Effect of T6 Fermentation on the Mycelial Growth and Morphological Characters of V. mali}

T6 fermentation with different dilution had a significant inhibitory effect on the mycelial growth of $V$. mali. The measurements of mycelial dry weight showed that the mycelium grew slowest in the stock solution of fermentation with a mycelial dry weight of $56.53 \pm 2.32 \mathrm{mg}$ at 5 days, which was reduced by $75.73 \%$ in comparison to $V$. mali in the control group (sterile water). The dry weight increased with the increase of fermentation dilutions (Table 2). There was a significant difference in the dry weight between the control group (232.92 $\pm 8.53 \mathrm{mg}$ ) and the $V$. mali treated with 32-fold dilution fermentation $(135.43 \pm 6.68 \mathrm{mg})(p<0.05)$. Microscopic observation revealed the T6 fermentation treatment also resulted in mycelium of $V$. mali was swelled and shrinkaged, and the protoplasm released (Figure 2C,F,G). It also enhanced hypha branching (Figure 2B), mycelium thickening, and mycelium cell wall rupturing and disintegrating (Figure 2D,H) compared with mycelium of $V$. mali culture alone (Figure 2A,E). 
Table 2. The inhibitory effect of Trichoderma longibrachiatum T6 fermentation against mycelial growth and conidia germination of Valsa mali.

\begin{tabular}{ccc}
\hline Dilution (Folds) & Germination Rates (\%) & Mycelial Dry Weight (mg) \\
\hline 0 & $1.67 \pm 0.52^{\mathrm{g}}$ & $56.53 \pm 2.32^{\mathrm{g}}$ \\
2 & $4.83 \pm 1.17^{\mathrm{f}}$ & $77.33 \pm 2.06^{\mathrm{f}}$ \\
4 & $8.83 \pm 0.75^{\mathrm{e}}$ & $94.40 \pm 2.20^{\mathrm{e}}$ \\
8 & $15.17 \pm 1.94^{\mathrm{d}}$ & $105.18 \pm 3.01^{\mathrm{d}}$ \\
16 & $33.17 \pm 3.43^{\mathrm{c}}$ & $115.63 \pm 2.65^{\mathrm{c}}$ \\
32 & $50.17 \pm 4.26^{\mathrm{b}}$ & $135.43 \pm 6.68^{\mathrm{b}}$ \\
$\mathrm{ck}$ & $83.50 \pm 3.21^{\mathrm{a}}$ & $232.92 \pm 8.53^{\mathrm{a}}$ \\
\hline
\end{tabular}

The value are means \pm standard deviations of six replicates and the different lowercase letters in the same column are significantly different at $p<0.05$ according to Duncan's new multiple range test and least significant difference test. The mycelial dry weight was determined at 5 days after treated with T6 fermentation, and the germination rates $(\%)$ were determined at $18 \mathrm{~h}$ after being treated with $\mathrm{T} 6$ fermentation. ck represents sterile water instead of T6 fermentation. " 0 " represents stock solution of T6 fermentation.

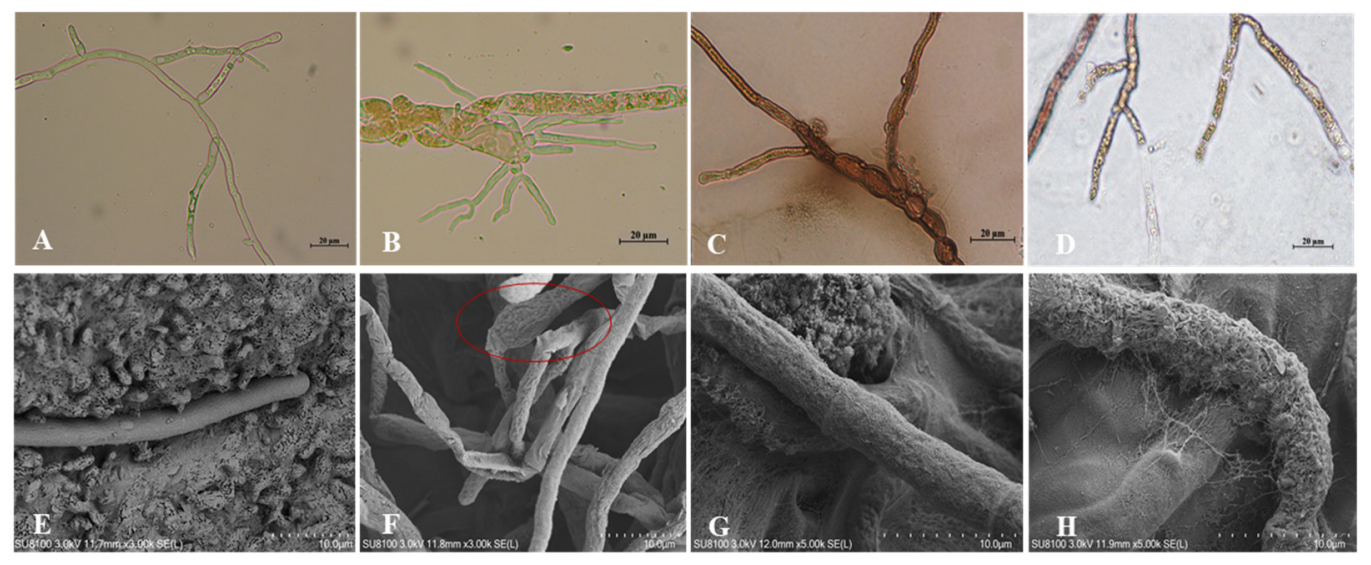

Figure 2. Micrographs of Valsa mali mycelium treated with Trichoderma longibrachiatum T6 fermentation stock solution for 5 days. Mycelium observed by light microscope (A-D) and scanning electron microscope (E-H). (A,E) Normal mycelium of V. mali. (B) Hypha to branch. (F) Treated mycelium with swelling (marked in red circle), shrinkage. $(\mathbf{C}, \mathbf{G})$ Protoplasm released. $(\mathbf{D}, \mathbf{H})$ Treated mycelium with hyphal disintegration.

\subsection{Inhibition of Conidia Germination of V. mali by T6 Fermentation}

Both spores in control group and the spores inoculated with T6 fermentation for $6 \mathrm{~h}$ expanded into an ellipse but did not germinate (Figure 3(b1,b2)). After $12 \mathrm{~h}$, spores began to germinate in sterile water (control group), being swollen but not germinated in fermentation treatment (Figure $3(\mathrm{c} 1, \mathrm{c} 2)$ ). After $18 \mathrm{~h}$, the spores in the $\mathrm{T} 6$ fermentation group began to germinate, but the germination rate $(1.67 \%)$ with stock solution of T6 fermentation (0-fold) was lower than that of the control group (83.50\%) (Figure 3(d1,d2)). It was $4.83 \%$ after the treatment with twofold dilution T6 fermentation. With the increase of dilution fold, the germination rates gradually increased to $50.17 \%$ when the fermentation was diluted by 32 -fold (Table 2). The length of germ tube produced by T6-treated spores was shorter than that of the control after $24 \mathrm{~h}$ (Figure $3(\mathrm{e} 1, \mathrm{e} 2)$ ). After $30 \mathrm{~h}$ of incubation, the hyphae in the control group were longer than those in the T6 fermentation-treated group (Figure $3(\mathrm{f} 1, \mathrm{f} 2)$ ). The spores were treated with fermentation and sterile water for $0 \mathrm{~h}$ as control (Figure 3(a1,a2)). 


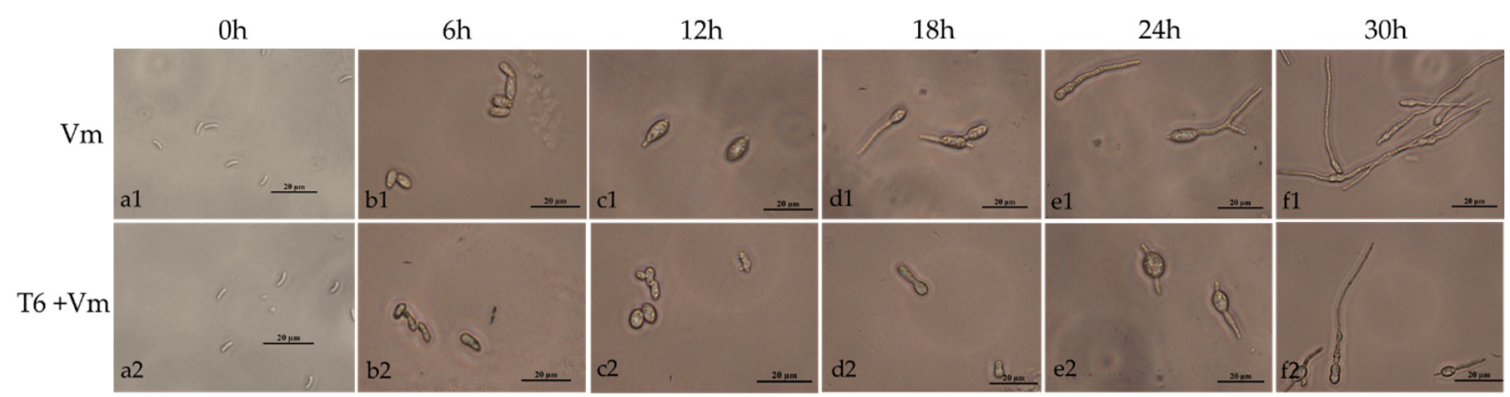

Figure 3. Inhibitory effect of Trichoderma longibrachiatum T6 fermentation on spore germination of Valsa mali in different time periods. The top panel $(\mathrm{Vm})$ represents the spores germinated in sterile water $(\mathbf{a} 1-\mathbf{f 1})$. The bottom panel $(\mathrm{T} 6+\mathrm{Vm})$ represents the spores germinated in $\mathrm{T} 6$ fermentation (a2-f2). The treatment time was indicated above images.

\subsection{Effect of T6 Fermentation on Lesion Development in Detached Twigs}

T6 fermentation had a significant inhibitory effect on the lesion development of V. mali on detached branches in comparison to the control, and there was a significant difference between them (Figure 4A,B). Compared with control, the area of the lesions on the treated branches was significantly smaller than that of control at 3, 5, 7, and 9 days after incubation (Figure 4A). The average area of the lesions in the treatment groups (treated with T6 fermentation) were decreased by $71.58 \%, 73.89 \%, 58.44 \%$, and $54.56 \%$ at $3,5,7$, and 9 days after incubation in comparison to the control group (treated with sterile water instead of T6 fermentation), respectively (Figure 4B).

Furthermore, T6 fermentation inhibited the production of pycnidia on the lesions after incubation from 9 to 15 days (Figure 4 C). On the 9th and 12th days after inoculation, there were $28.33 \pm 2.42$ and $38.83 \pm 3.19$ pycnidia on the lesion surface in control group, respectively, while significantly less pycnidia $(4.83 \pm 0.75$ and $6.50 \pm 0.55)$ were produced on the lesion surface treated with T6 fermentation $(p<0.05)$. After 15 days of inoculation, the number of pycnidia in the treatment groups was $8.50 \pm 1.05$, which was $83.65 \%$ less than that of the control (Figure 4D).

\subsection{Cell Wall-Degrading Enzyme Activity of V. mali after T6 Fermentation Treatments}

The activity of cell wall-degrading enzyme pectinase, cellulase, and xylanase of $V$. mali was significantly lower than that of the control during the cultivation process after treatment with T6 fermentation. The activity of pectinase was the highest, followed by cellulase, and then xylanase. The activity of pectinase decreased significantly in different periods after the fermentation treatment. The highest activity of pectinase reached $4.20 \pm 0.33 \mathrm{U} / \mathrm{mL}$ on the 9th day, which was $49.28 \%$ lower than that of the control (Figure 5A). On the 11th day, the activity of pectinase was $3.02 \pm 0.17 \mathrm{U} / \mathrm{mL}$, which was significantly lower than control group $(6.67 \pm 0.05 \mathrm{U} / \mathrm{mL})(p<0.05)$. The activities of cellulase (Figure $5 \mathrm{~B})$ and xylanase (Figure $5 \mathrm{C}$ ) were $0.91 \pm 0.01$ and $0.31 \pm 0.03 \mathrm{U} / \mathrm{mL}$, respectively, on fifth and seventh days in treated groups, which were $57.28 \%$ and $51.56 \%$ lower than those in the control, respectively. The activities of cellulase and xylanase of $V$. mali treated with T6 increased along with the culture time and reached the maximum value on the 11th day, being $2.45 \pm 0.03 \mathrm{U} / \mathrm{mL}$ and $0.52 \pm 0.08 \mathrm{U} / \mathrm{mL}$, respectively. These were significantly lower than the control group $(3.81 \pm 0.16 \mathrm{U} / \mathrm{mL}$ and $0.88 \pm 0.08 \mathrm{U} / \mathrm{mL}$, respectively) $(p<0.05)$. 

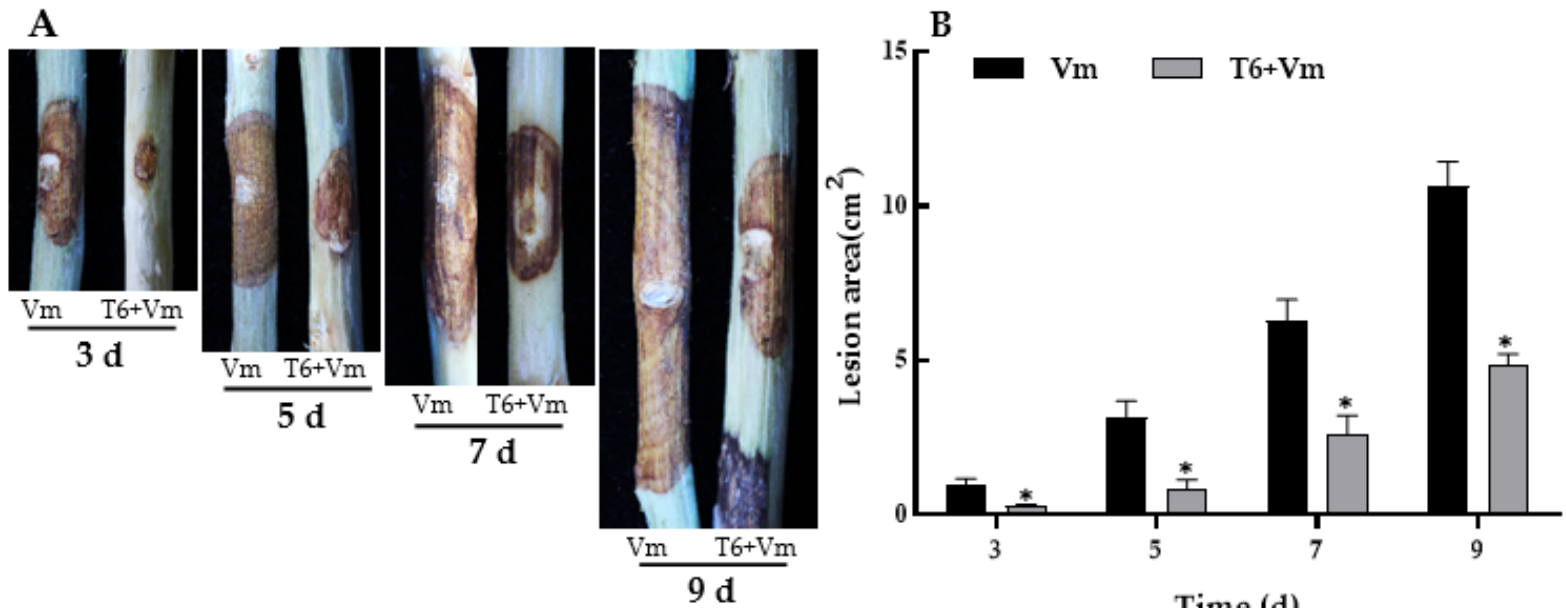

$\mathrm{C}$
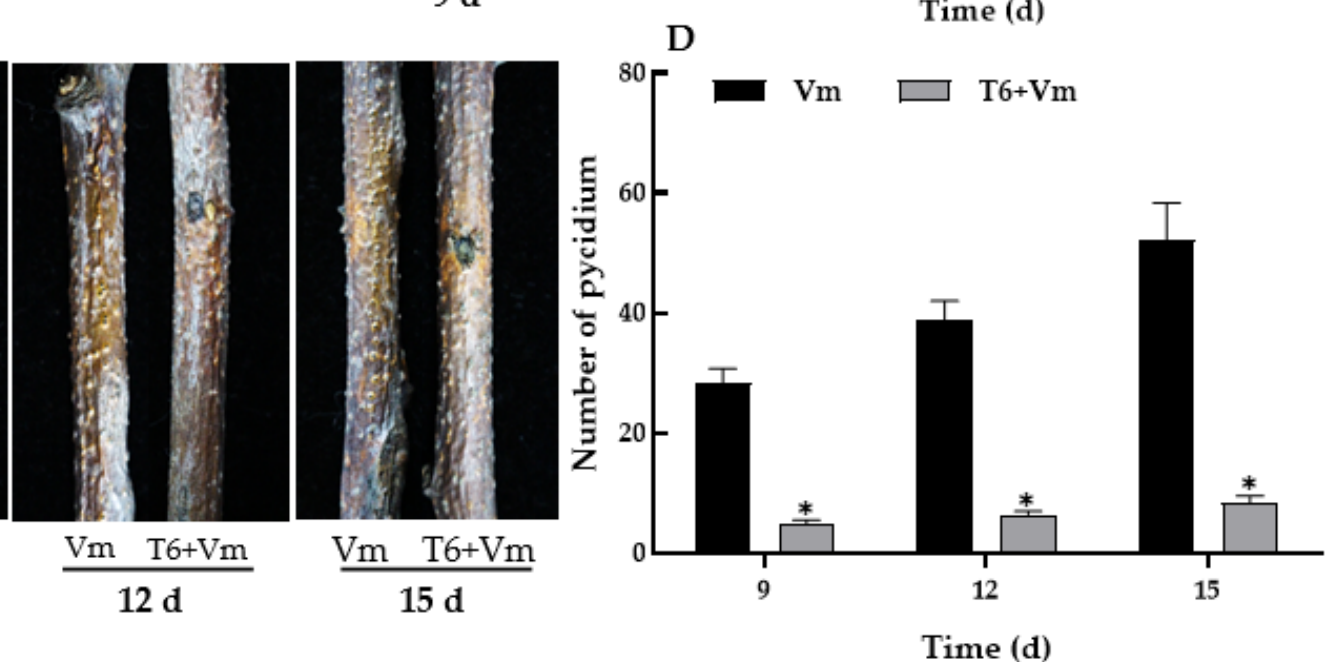

Figure 4. Effect of Trichoderma longibrachiatum T6 fermentation on pathogenicity of Valsa mali. (A) Development of lesion on the detached branches infected with $V$. mali treated with T6. (B) Quantification of the lesion area. (C) Formation of pycnidia on the detached branches infected with $V$. mali treated with T6 fermentation. (D) The number of pycnidia formed. Small bars represent the standard deviations of the means. Each test was repeated three times. Asterisk indicates the significant difference between the control group and the treatment group $(p<0.05)$.

\subsection{Expression of Genes of V. mali after T6 Fermentation Treatments}

The RT-qPCR results showed that T6 fermentation downregulated the expression of the genes involved in growth, conidiation, virulence, cell wall-degrading enzymes, and metabolic pathway of $V$. mali at 5 days after inoculation (Figure 6). Compared with control, the expression level of cell wall-degrading enzyme-related genes was downregulated by 0.70-fold, 0.54-fold, 0.21-fold, and 0.29-fold for xylanase I, Pectinase 2, $\beta$-glucosidase 1, and $\beta$-glucosidase 2 , respectively; the growth, conidial development, secondary metabolism, and virulence related genes $V m V e A, V m V e l B, G v m 2$, and Gvm3 were downregulated by 0.35- to 0.63-fold; and the metabolism-related genes (superoxide dismutase, catalase, citrate synthase, malate synthase) and the pathogenic effectors VmPxE1 were downregulated by 0.38- to 0.58-fold and 0.53-fold, respectively. 
A

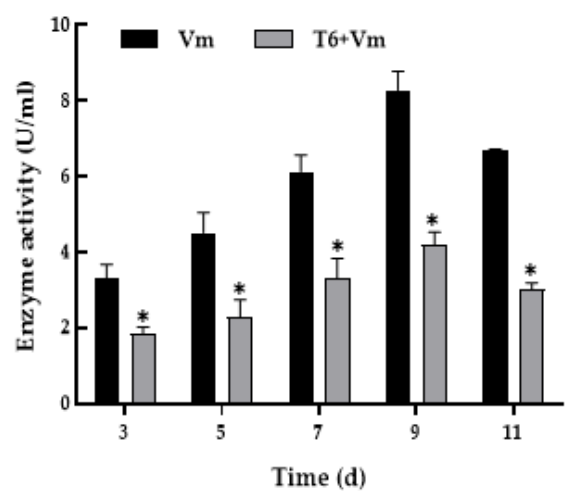

C

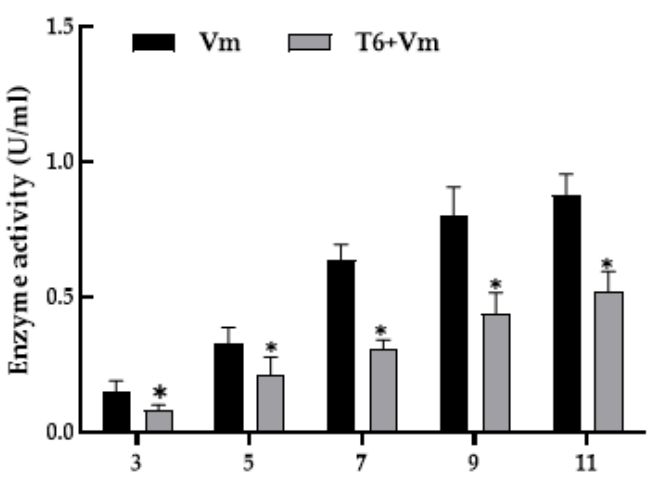

Time (d)

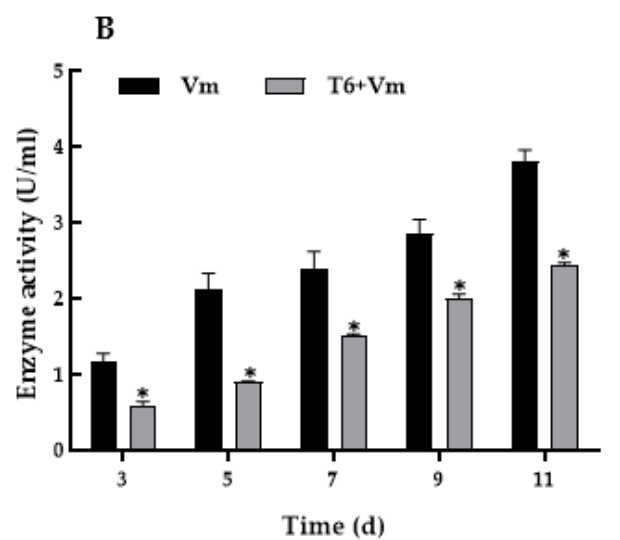

Time (d)

Figure 5. The activity of cell wall-degrading enzyme of Valsa mali treated with Trichoderma longibrachiatum T6 fermentation at stock solution. (A) Pectinase activity. (B) Cellulase activity. (C) Xylanase activity. The "T6 $+\mathrm{Vm}$ " represents liquid medium inoculated with Valsa mali and $\mathrm{T} 6$ fermentation. "Vm" represents liquid medium inoculated with Valsa mali only. The abscissa indicates that the enzyme activity of $V$. mali was measured at 3, 5, 7, 9, and 11 days after T6 fermentation treatment. Small bars represent the standard deviations of the means, and an asterisk indicates the significant difference between the control group and the treatment group $(p<0.05)$.

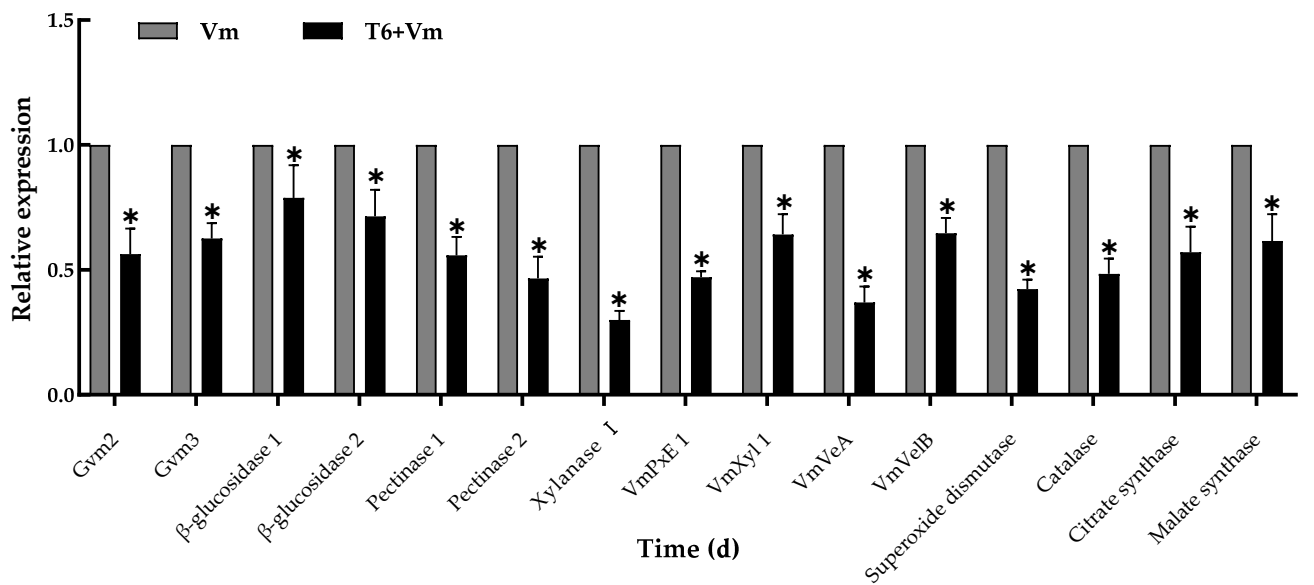

Figure 6. Relative expression level of 15 genes of Valsa mali after treatment with Trichoderma longibrachiatum $\mathrm{T} 6$ fermentation at stock solution for 5 days. The relative expressions represented in the histogram are the average values of three replicates. Asterisks indicate the significant difference between the control group and the treatment group $(p<0.05)$, and the small bars represent the standard deviations. The expression level of the control samples (Vm) without T6 treatment was normalized to 1 . 


\section{Discussion}

This study focused on evaluating the antagonistic effect of T. longibrachiatum T6 (T6) fermentation against $V$. mali. Our results showed that the $\mathrm{T} 6$ fermentation could be used as an effective biocontrol agent to control the disease that caused by V. mali through inhibiting the growth of its colonies even reproduction and pathogenicity. Furthermore, our study demonstrated that T6 fermentation significantly decreased the activity of cell wall-degrading enzymes and downregulated the expression of genes related to cell walldegrading enzyme, pathogenic factor, and growth metabolism of $V$. mali at physiological and molecular levels.

Trichoderma has been applied as biocontrol agent against the plant pathogen, including $V$. mali, which has been confirmed in vitro [36,37]. Our results indicate that $\mathrm{T} 6$ fermentation presented great inhibitory potential against $V$. mali. In a laboratory test, different dilutions of T6 fermentation had a strong antifungal effect on the colony growth of $V$. mali. There were some other species of Trichoderma that exhibited antifungal effects on the colony growth and reproduction of other pathogens, i.e., T. pseudokoningii, which significantly inhibited the growth and sporulation of B. cinerea [38]; T. harzianum inhibited the growth and reproduction of some pathogenic fungi including Fusarium spp., R. solani, and Macrophomina phaseolina $[39,40]$. Interestingly, we found that T6 fermentation also decreased the number of pycnidia of $V$. mali significantly on PDA media.

In addition, a number of studies have demonstrated that some biocontrol agents suppressed the plant pathogenic fungi by inhibiting their spore germination and mycelial growth. Bacillus amyloliquefaciens GB1 significantly reduced the conidia germination and the hyphal growth of $V$. mali by producing the antifungal metabolites [41]. In our present study, the conidia germination rates and mycelial growth were decreased by $98.1 \%$ and $75.7 \%$, respectively, after treatment with $\mathrm{T} 6$ fermentation. In contrast, the antifungal activity of nonanoic acid against Crinipellis perniciosa and Moniliophthora roreri that was secreted from $T$. harzianum had $75 \%$ suppression of spore germination and $70 \%$ reduction of mycelial growth [42]. Furthermore, our results showed that $\mathrm{T} 6$ fermentation significantly decreased and delayed the spore germination, as well as suppressed the mycelial growth by rupturing and deforming the mycelial cell wall of $V$. mali. The possible mechanism may have been due to the production of cell wall-degrading enzymes and the antagonistic compounds from T6 fermentation. Previous studies reported that the cell wall-degrading enzyme of Trichoderma plays an important role in changing the morphological structure of mycelium and in inhibiting mycelial growth, including protease, chitinase, and glucanase [43,44]. Additionally, the secondary metabolites produced by Trichoderma including the diketopiperazines, ergosterol derivatives, and peptaibols had a significant antifungal effect on B. cinerea [38]. Bacillus velezensis was shown to have the ability to change the morphological structure of $V$. mali mycelium, including hyphal deformities, wrinkles, and ruptures [45]; our previous study found that the secondary metabolites (1,2-benzenedicarboxylicacid, bis-(2-methylpropyl)ester (DIBP), (Z)-octadec-9-enoic acid, 1,2-benzenedicarboxylic acid, mono-(2-ethylhexyl)ester (MEHP), and (Z)-13-docosenamide) of T. longibrachiatum T6 had inhibitory rates of 95\% against $V$. mali [22]. Meanwhile, the volatile organic compounds (VOCs) produced by Trichoderma play a major role in inhibiting the mycelial growth of Sclerotinia spp. and Fusarium oxysporum [46].

Previous studies showed that smearing of Saccharothrix yanglingensis Hhs.015 (Hhs.015) fermentation on detached branches inhibited the lesion expansion and pycnidial production of $V$. mali, and the lesion expansion rate was reduced by $50 \%$ after treatment with Hhs.015 fermentation [47]. Similarly, the strain of B. amyloliquefaciens GB1 exhibited higher activity on decreasing of $V$. mali infection to apple branches [41]. In our study, T6 fermentation reduced the expansion area of lesions on detached branches and the number of pycnidia that was produced on the lesions significantly after application of T6 fermentation and inoculation of $V$. mali in comparison to the previous study. These findings provided a basis for the further field trials. The possible mechanism of T6 fermentation in controlling of apple Valsa canker disease on detached branches is response for the production of cell wall- 
degrading enzymes and antagonistic compounds, which decreased the pathogen ( $V$. mali) growth, reproduction, and pathogenicity. A previous study showed that the gluconase, chitinase, and protease of Aureobasidium pullulans can suppress the growth and infection of B. cinerea and Penicillium expansum on apple fruit [48].

The mechanism of V. mali infection is complex, in which cell wall-degrading enzymes, secondary metabolites, and effector proteins play an important role in increasing its pathogenic activity [49-51], as well as promoting its invasion and colonization of host tissues [52]. In a preliminary study on the infection of $V$. mali on apple tree bark, it was found that the infection process was related to pectin catabolism, and that hydrolase activity and secondary metabolite biosynthesis, and four pectinases were highly abundant during infection $[27,34,53]$. In our present study, the results showed that $\mathrm{T} 6$ fermentation reduced the activity of cell wall-degrading enzymes (pectinase, cellulase, and xylanase) of $V$. mali. In particular, the enzyme activity of pectinase was significantly decreased by $49.28 \%$, which indicates that $\mathrm{T} 6$ fermentation could reduce the pathogenicity, invasion, and colonization of $V$. mali on apple trees. It has been reported that $T$. virens ZT05 significantly inhibited the catalase and superoxide dismutase of $R$. solani [54]; Hhs.015 downregulated the glycoside hydrolase gene expression including pectinase genes of V. mali [34]. Our present study found that in the genes related to the cell wall-degrading enzymes of pectinase, cellulase, and xylanase, metabolism and pathogenicity of $V$. mali were significantly downregulated after inoculation with $\mathrm{T} 6$ fermentation.

\section{Conclusions}

T6 fermentation effectively exhibited inhibitory activity on $V$. mali growth, reproduction, and pathogenicity in vitro and detached branches in vivo. The possible mechanisms of T6 fermentation against $V$. mali are response for inhibiting the mycelial growth and spore germination, reducing the lesion expanding and pycnidia formation and decreasing the pathogenicity and pathogenic enzymes activity of $V$. mali through downregulating its related gene expression. More in-depth research is needed focus on developing an effective T6 agent in controlling of apple Valsa canker in the field.

Supplementary Materials: The following supporting information can be downloaded at https: / /www.mdpi.com/article/10.3390/jof8020113/s1, Table S1. Primers for RT-qPCR assay.

Author Contributions: Conceptualization, S.-W.Z. and B.-L.X.; data curation, N.Z.; formal analysis, N.Z. and J.-J.Z.; funding acquisition, S.-W.Z.; methodology, N.Z.; project administration, S.-W.Z. and B.-L.X.; software, N.Z.; supervision, S.-W.Z. and B.-L.X.; writing-original draft, N.Z.; writingreview and editing, J.-J.Z., S.-W.Z. and B.-L.X. All authors have read and agreed to the published version of the manuscript.

Funding: This work was supported by Fuxi Outstanding Talent Cultivation Program, Gansu Agricultural University (Project Gaufx-03J03), Longyuan Youth Innovation and Entrepreneurship Talent Project (2021LQTD27), and Program of Introducing Talents to Chinese Universities (111 Program no. D20023) to J.-J.Z.

Institutional Review Board Statement: Not applicable.

Informed Consent Statement: Not applicable.

Data Availability Statement: The data in this study are available on request from the corresponding author/first author.

Conflicts of Interest: The authors declare that the research was conducted in the absence of any commercial or financial relationships that could be construed as a potential conflict of interest.

\section{References}

1. Wang, X.L.; Wei, J.L.; Huang, L.L.; Kang, Z.S. Re-evaluation of pathogens causing Valsa canker on apple in China. Mycologia 2011, 103, 317-324. [CrossRef]

2. Vasilyeva, L.; Kim, W.G. Valsa mali miyabe et yamada, the causal fungus of apple tree canker in East Asia. Mycobiology 2000, 28, 153-157. [CrossRef] 
3. Abe, K.; Kotoda, N.; Kato, H.; Soejima, J. Genetic studies on resistance to Valsa canker in apple: Genetic variance and breeding values estimated from intra- and inter-specific hybrid progeny populations. Tree Genet. Genomes 2011, 7, 363-372. [CrossRef]

4. $\quad$ Lee, D.H.; Lee, S.W.; Choi, K.H.; Kim, D.A.; Uhm, J.Y. Survey on the occurrence of apple diseases in Korea from 1992 to 2000. Plant Pathol. J. 2006, 22, 375-380. [CrossRef]

5. Wang, S.T.; Hu, T.L.; Wang, Y.N.; Luo, Y.; Michailides, T.J.; Cao, K.Q. New understanding on infection processes of Valsa canker of apple in China. Eur. J. Plant Pathol. 2016, 146, 531-540. [CrossRef]

6. Wang, X.L.; Zang, R.; Yin, Z.Y.; Kang, Z.S.; Huang, L.L. Delimiting cryptic pathogen species causing apple Valsa canker with multilocus data. Ecol. Evol. 2014, 4, 1369-1380. [CrossRef]

7. Li, B.H.; Wang, C.X.; Dong, X.L. Research progress in apple diseases and problems in the disease management in China. Plant Protect. 2013, 39, 46-54. [CrossRef]

8. Lei, P.; Xu, Y.; Du, J.; Yang, X.L.; Yuan, H.Z.; Xu, G.F.; Ling, Y. Design, synthesis and fungicidal activity of N-substituted benzoyl-1,2,3,4-tetrahydroquinolyl-1-carboxamide. Bioorg. Med. Chem. 2016, 26, 2544-2546. [CrossRef]

9. Yan, W.; Wei, P.; Wang, D.; Hao, S.H.; Li, W.W.; Ding, F. Design, synthesis, antifungal activity, and 3D-QSAR of coumarin derivatives. J. Pestic. Sci. 2018, 43, 88-95. [CrossRef]

10. Zhang, X.B.; Lei, P.; Sun, T.D.; Jin, X.Y.; Yang, X.L.; Ling, Y. Design, synthesis, and fungicidal activity of novel thiosemicarbazide derivatives containing piperidine fragments. Molecules 2017, 22, 2085. [CrossRef]

11. Abe, K.; Kotoda, N.; Kato, H.; Soejima, J. Resistance sources to Valsa canker (Valsa ceratosperma) in a germplasm collection of diverse Malus species. Plant Breed. 2010, 126, 449-453. [CrossRef]

12. Wang, Y.; Sun, Y.; Han, L.R.; Zhang, X.; Feng, J.T. Potential use of cuminic acid as a botanical fungicide against Valsa mali. Microb. Pathog. 2017, 106, 9-15. [CrossRef] [PubMed]

13. Kim, B.S.; Hwang, B.K. Microbial fungicides in the control of plant diseases. J. Phytopathol. 2007, 155, 641-653. [CrossRef]

14. Yin, Z.Y.; Liu, H.Q.; Li, Z.P.; Ke, X.W.; Dou, D.L.; Gao, X.N.; Song, N.; Dai, Q.Q.; Wu, Y.X.; Xu, J.R. Genome sequence of Valsa canker pathogens uncovers a potential adaptation of colonization of woody bark. New Phytol. 2015, 208, 1202-1216. [CrossRef] [PubMed]

15. Miles, L.A.; Lopera, C.A.; González, S.; García, M.C.C.D.; Franco, A.E.; Restrepo, S. Exploring the biocontrol potential of fungal endophytes from an Andean Colombian Paramo ecosystem. Biocontrol 2012, 57, 697-710. [CrossRef]

16. Atanasova, L.; Crom, S.L.; Gruber, S.; Coulpier, F.; Verena, S.S.; Kubicek, C.P.; Druzhinina, I.S. Comparative transcriptomics reveals different strategies of Trichoderma mycoparasitism. BMC Genom. 2013, 14, 121. [CrossRef]

17. Guo, R.T.; Wang, Z.Y.; Zhou, C.; Liu, Z.H.; Zhang, P.; Fan, H.J. Transcriptomic analysis reveals biocontrol mechanisms of Trichoderma harzianum ACCC30371 under eight culture conditions. J. For. Res. 2019, 31, 1863-1873. [CrossRef]

18. Ahluwalia, V.; Kumar, J.; Rana, V.S.; Sati, O.P.; Walia, S. Comparative evaluation of two Trichoderma harzianum strains for major secondary metabolite production and antifungal activity. Nat. Prod. Res. 2015, 29, 914-920. [CrossRef]

19. Pakora, G.-A.; Mpika, J.; Kone, D.; Ducamp, M.; Kebe, I.; Nay, B.; Buisso, D. Inhibition of Phytophthora species, agents of cocoa black pod disease, by secondary metabolites of Trichoderma species. Environ. Sci. Pollut. Res. 2018, 25, 29901-29909. [CrossRef]

20. Verma, M.; Brar, S.K.; Tyagi, R.D.; Sahai, V.; Prévost, D.; Valéro, J.R.; Surampalli, R.Y. Bench-scale fermentation of Trichoderma viride on wastewater sludge: Rheology, lytic enzymes and biocontrol activity. Enzyme Microb. Technol. 2007, 41, 764-771. [CrossRef]

21. Yang, X.M.; Chen, L.H.; Yong, X.Y.; Shen, Q.R. Formulations can affect rhizosphere colonization and biocontrol efficiency of Trichoderma harzianum SQR-T037 against Fusarium wilt of cucumbers. Biol. Fertil. Soils. 2011, 47, 239-248. [CrossRef]

22. Zhang, S.W.; Xu, B.L.; Zhang, J.H.; Gan, Y.T. Identification of the antifungal activity of Trichoderma longibrachiatum T6 and assessment of bioactive substances in controlling phytopathgens. Pestic. Biochem. Physiol. 2018, 147, 59-66. [CrossRef] [PubMed]

23. Liu, J.; Zhang, Y.; Shen, Z.Y.; Zhang, S.W.; Xue, Y.Y.; Liang, Q.L.; Tao, F.; Xu, B.L. Inhibitory effect of Trichoderma longibrachiatum T6 on Fusarium. oxysporum. Acta Agric. Boreali-Occident. Sin. 2020, 29, 1891-1897.

24. Chen, X.L.; Niu, C.W.; Li, B.H.; Li, G.F.; Wang, C.X. The kinds and activities of cell wall-degrading enzymes produced by Valsa ceratosperma. Acta Agricu. Boreali-Occident. Sin. 2012, 27, 207-212. [CrossRef]

25. Gairola, C.; Powell, D. Extracellular enzymes and pathogenesis by peach Cytosporas. J. Phytopathol. 1971, 72, 305-314. [CrossRef]

26. Ke, X.W.; Huang, L.L.; Han, Q.M.; Gao, X.; Kang, Z.S. Histological and cytological investigations of the infection and colonization of apple bark by Valsa mali var. mali. Australas. Plant Pathol. 2013, 42, 85-93. [CrossRef]

27. Ke, X.W.; Yin, Z.Y.; Song, N.; Dai, Q.Q.; Voegele, R.T.; Liu, Y.Y.; Wang, H.Y.; Gao, X.N.; Kang, Z.S.; Huang, L.L. Transcriptome profiling to identify genes involved in pathogenicity of Valsa mali on apple tree. Fungal Genet. Biol. 2014, 68, 31-38. [CrossRef]

28. Song, N.; Dai, Q.Q.; Zhu, B.T.; Wu, Y.X.; Xu, M.; Voegele, R.T.; Gao, X.N.; Kang, Z.S.; Huang, L.L. G $\alpha$ proteins Gvm2 and Gvm3 regulate vegetative growth, asexual development, and pathogenicityon apple in Valsa mali. PLoS ONE 2017, 12, e0173141. [CrossRef]

29. Wu, Y.X.; Xu, L.S.; Yin, Z.Y.; Dai, Q.Q.; Gao, X.; Feng, H.; Voegele, R.T.; Huang, L.L. Two members of the velvet family, VmVeA and VmVelB, affect conidiation, virulence and pectinase expression in Valsa mali. Mol. Plant Pathol. 2017, 19, 1639-1651. [CrossRef]

30. Etebarian, H.R.; Sholberg, P.L.; Eastwell, K.C.; Sayler, R.J. Biological control of apple blue mold with Pseudomonas fluorescens. Can. J. Microbiol. 2005, 51, 591-598. [CrossRef]

31. Zang, R.; Huang, L.L.; Kang, Z.S.; Wang, X.L. Biological characteristics and pathogenicity of different isolates of Cytospora spp. isolated from apple trees in Shaanxi province. Acta Phytopathol. Sin. 2007, 37, 343-351. [CrossRef] 
32. Pietro, A.D.; Roncero, M.I.G. Endopolygalacturonase from Fusarium oxysporum f. sp. lycopersici: Purification, characterization, and production during infection of tomato plants. Phytopathology 1996, 86, 1324-1330. [CrossRef]

33. Miller, G.L. Use of dinitrosalicylic acid reagent for determination of reducing sugar. Anal. Biochem. 1959, 31, 426-428. [CrossRef]

34. Liu, C.; Fan, D.Y.; Li, Y.F.; Chen, Y.; Huang, L.L.; Yan, X. Transcriptome analysis of Valsa mali reveals its response mechanism to the biocontrol actinomycete Saccharothrix yanglingensis Hhs.015. BMC Microbiol. 2018, 18, 90. [CrossRef]

35. Yin, Z.Y.; Ke, X.W.; Huang, D.X.; Gao, X.N.; Voegele, R.T.; Kang, Z.S.; Huang, L.L. Validation of reference genes for gene expression analysis in Valsa mali var. mali using real-time quantitative PCR. World J. Microbiol. Biotechnol. 2013, 29, 1563-1571. [CrossRef]

36. Narayanasamy, P.; Thokala, P.; Muthukrishnan, S.; Kamil, D. Screening of different Trichoderma species against agriculturally important foliar plant pathogens. J. Environ. Biol. 2015, 36, 191-198. Available online: https://europepmc.org/article/MED/2653 6792 (accessed on 21 November 2021).

37. Zhang, X.J.; Harvey, P.R.; Stummer, B.E.; Warren, R.A.; Zhang, G.Z.; Guo, K.; Li, J.S.; Yang, H.T. Antibiosis functions during interactions of Trichoderma afroharzianum and Trichoderma gamsii with plant pathogenic Rhizoctonia and Pythium. Funct. Integr. Genom. 2015, 15, 599-610. [CrossRef]

38. Zhao, P.; Ren, A.; Dong, P.; Sheng, Y.; Li, D. Antimicrobial peptaibols, Trichokonins, inhibit mycelial growth and sporulation and induce cell apoptosis in the pathogenic fungus Botrytis cinerea. Appl. Biochem. Microbiol. 2018, 54, 396-403. [CrossRef]

39. Zaki, S.A.; Ouf, S.A.; Albarakaty, F.M.; Habeb, M.M.; Aly, A.A.; Abd-Elsalam, K.A. Trichoderma harzianum-mediated ZnO nanoparticles: A green tool for controlling soil-borne pathogens in cotton. J. Fungi 2021, 7, 952. [CrossRef]

40. Daniel, H. Antibiosis in vitro of Trichoderma strains metabolic extract on mycelial growth and reproductive capacity of Fusarium oxysporum isolated from pepper plants (Capsicum annuum L.). Br. Biotech. J. 2014, 4, 387-399. [CrossRef]

41. Zhang, J.X.; Gu, Y.B.; Chi, F.M.; Ji, Z.R.; Wu, J.Y.; Dong, Q.L.; Zhou, Z.S. Bacillus amyloliquefaciens GB1 can effectively control apple valsa canker. Biol. Control 2015, 88, 1-7. [CrossRef]

42. Aneja, M.; Gianfagna, T.J.; Hebbar, P.K. Trichoderma harzianum produces nonanoic acid, an inhibitor of spore germination and mycelial growth of two cacao pathogens. Physiol. Mol. Plant Pathol. 2005, 67, 304-307. [CrossRef]

43. Ghasemi, S.; Safaie, N.; Shahbazi, S.; Shams-Bakhsh, M.; Askari, H. The role of cell wall degrading enzymes in antagonistic traits of Trichoderma virens against Rhizoctonia solani. Iran. J. Biotechnol. 2020, 18, e2333. [CrossRef] [PubMed]

44. Javeria, S.; Kumar, A.; Kharkwal, A.C.; Varma, A.; Srinivasa, N.; Sharma, P. Evaluation of rhizospheric Trichoderma species strains for producing cell wall-degrading and defense related enzymes in response to Fusarium oxysporum f. sp. lentis. Indian Phytopathol. 2020, 73, 461-467. [CrossRef]

45. Liu, R.H.; Li, J.Y.; Zhang, F.R.; Zheng, D.; Chang, Y.L.; Xu, L.S.; Huang, L.L. Biocontrol activity of Bacillus velezensis D4 against apple Valsa canker. Biol. Control 2021, 163, 104760. [CrossRef]

46. Rajani, P.; Chandrasekaran, R.; Vasanthakumari, M.M.; Olsson, S.B.; Ravikanth, G.; Shaanker, R.U. Inhibition of plant pathogenic fungi by endophytic Trichoderma spp. through mycoparasitism and volatile organic compounds. Microbiol. Res. 2020, $242,126595$. [CrossRef]

47. Li, Z.P.; Gao, X.N.; Fan, D.Y.; Yan, X.; Kang, Z.S.; Huang, L.L. Saccharothrix yanglingensis Strain Hhs.015 is a promising biocontrol agent on apple Valsa canker. Plant Dis. 2015, 100, 510-514. [CrossRef]

48. Castoria, R.; De Curtis, F.; Lima, G.; Caputo, L.; Pacifico, S.; De Cicco, V. Aureobasidium pullulans (LS-30) an antagonist of postharvest pathogens of fruits: Study on its modes of action. Postharvest Biol. Technol. 2001, 22, 7-17. [CrossRef]

49. Feng, Y.Q.; Yin, Z.Y.; Wu, Y.X.; Xu, L.S.; Du, H.X.; Wang, N.N.; Huang, L.L. LaeA controls virulence and secondary metabolism in apple canker pathogen Valsa mali. Front. Microbiol. 2020, 11, 2693. [CrossRef] [PubMed]

50. Li, Z.P.; Yin, Z.Y.; Fan, Y.Y.; Xu, M.; Kang, Z.S.; Huang, L.L. Candidate effector proteins of the necrotrophic apple canker pathogen Valsa mali can suppress BAX-induced PCD. Front. Plant Sci. 2015, 6, 579. [CrossRef]

51. Wu, Y.X.; Xu, L.S.; Liu, J.; Yin, Z.Y.; Gao, X.N.; Feng, H.; Huang, L.L. A mitogen-activated protein kinase gene (VmPmk1) regulates virulence and cell wall degrading enzyme expression in Valsa mali. Microb. Pathog. 2017, 111, 298-306. [CrossRef] [PubMed]

52. Xu, C.J.; Wu, Y.X.; Dai, Q.Q.; Li, Z.P.; Gao, X.N.; Huang, L.L. Function of polygalacturonase genes Vmpg7 and Vmpg8 of Valsa mali. Sci. Agric. Sin. 2016, 8, 1489-1498. [CrossRef]

53. Xu, M.; Guo, Y.; Tian, R.Z.; Gao, C.; Guo, F.R.; Voegele, R.T.; Bao, J.Y.; Li, C.J.; Jia, C.H.; Feng, H.; et al. Adaptive regulation of virulence genes by microRNA-like RNAs in Valsa mali. New Phytol. 2020, 227, 899-913. [CrossRef] [PubMed]

54. Halifu, S.; Deng, X.; Song, X.S.; Song, R.Q.; Liang, X. Inhibitory mechanism of Trichoderma virens ZT05 on Rhizoctonia solani. Plants 2020, 9, 912. [CrossRef] 